\title{
WORLD'S POULTRY SCIENCE
}

\section{JOURNAL}

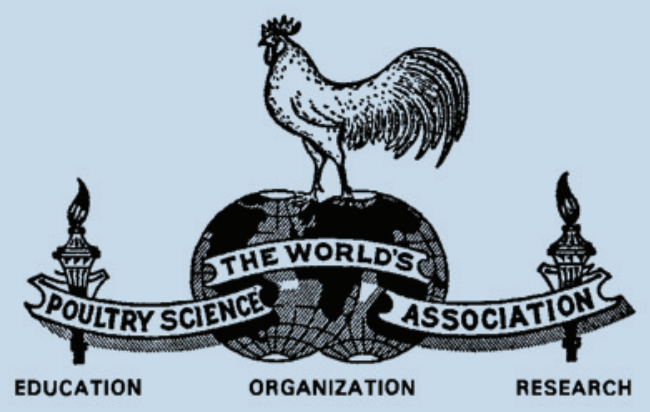

VOLUME 41

\section{CONTENTS}

Title Page . . . . . . . 97

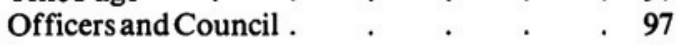

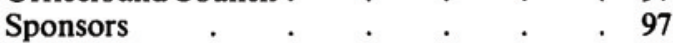

Branch Secretaries 。 $\quad . \quad$. $\quad .98$

\section{Main Articles}

Probiotics in Poultry Nutrition-A ReviewM. A. Jernigan, R. D. Miles and A. S. Araja

Stimulation of Adrenals during the Critical Periods of Development and Production in Fowls-Anna Ja. Avrutina, Irina L.

Galpern andS.M. Kisljute

Colostomy of the Fowl-J. G. Dingle and J.M.McNab

Genetic Manipulation of the Domestic FowlA Review-B. M. Freeman and L. I. Messer 124

Biological Conversion of Poultry and Animal Waste to a Feedstuff for Poultry-A. R. El. Boushy, G. J. Klassen and E. H. Ketalaars 133

Light and Production Performance in Turkeys-R. A. Singh

Random Sample Poultry Tests-Their

Development and Present Status in European Countries-W. Hartmann

\begin{abstract}
Association News
Minutes of the 18th Meeting of the Executive Committee at Las Vegas including Reports of the Secretary, Treasurer and Editor/ Production Manager for 1984 .
\end{abstract}

\section{Branch News}

Indian Branch . $\quad . \quad$. $\quad . \quad . \quad .169$

Lebanese Branch $\quad . \quad$. $\quad . \quad$. $\quad .169$

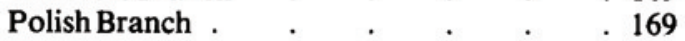

U.K.Branch . $\quad . \quad$. $\quad . \quad 169$

\section{European Federation News}

Minutes of the 27th Meeting of the Executive Committee, Helsinki . . . 170

Minutes of the 28th Meeting of the Executive Committee, Veyle . . . . . 171

Working Group No 3 (Breeding/Genetics)Report for 1984 . $\quad . \quad . \quad . \quad .173$

Book Reviews . . . . . . $\quad .174$

Forthcoming Events . . . . . 175 